\title{
Assessing Adaptation Strategies to the Impacts of Climate Change: A Case Study of Pungu - Upper East Region, Ghana
}

\author{
Boateng Ampadu ${ }^{1}$, Evans Frimpong Boateng, ${ }^{2, *}$, Miriam Adjei Abassa ${ }^{3}$ \\ ${ }^{1}$ Department of Earth and Environmental Science, University for Development Studies, Ghana \\ ${ }^{2}$ School of Materials Science and Engineering, Nanjing University of Science and Technology, P.R. China \\ ${ }^{3}$ Department of Earth and Environmental Sciences, University for Development Studies, Ghana
}

Copyright(C2018 by authors, all rights reserved. Authors agree that this article remains permanently open access under the terms of the Creative Commons Attribution License 4.0 International License

\begin{abstract}
The research was undertaken at Pungu in the Kassena Nankana Municipal Assembly in the Upper East Region of Ghana, in order to assess the adaptation strategies of the impacts of climate change by indigenes with respect to the unpredictable change in climate at the area (Pungu). The study was based on climate change impact on health, water resources, agriculture and socio-economic statuses as questionnaire and interview were the scientific methods utilized in this findings. The results from the assessment showed that, indigenes sleep either outside or inside which is dependent on prevailing atmospheric temperature to prevent heat related illness such as cerebrospinal meningitis (CSM) among others. The study also found out that unpredictable climate change had detrimental impact on water resources and agriculture in the area which inevitably affected their social and economic works. So, adaptation strategies such as hand-dug wells and boreholes are resorted to cope with the impacts of climate change on the aforementioned statuses. Frequent seminars and public education on the awareness of climate change, impacts and adaptation strategies are recommended.
\end{abstract}

Keywords Climate Change, Pungu, Agriculture, Ghana

\section{Introduction}

Climate change is among the defining issues of our time. Humans are altering earth's climate based on many lines of findings that are certain throughout the world. The cycle of climate and various activities of man have resulted in the increasing problem of climate-corresponding changes. The evidence is unambiguous that most developing countries have problem relating to food security due to variability of rainfall. Ghana is part of the vulnerable countries when it comes to climate change maters since agriculture is one of the economic pillars but the sector solely depends on rain fed. Moreover, Unforeseeable and extreme weather events impact are created by global warming and increasingly affect crop growth, availability of soil water and forest fires [1]. Soil erosion, droughts, floods, rise in sea level with predominant infection of diseases and pest infestations are also part of these severe weather events. It may be a modification in average atmospheric settings, or in the distribution of weather around the intermediate status (i.e., more or fewer extreme weather events). Definite human activities have also been identified as vital causes of recent climate change, often referred to as global warming. Increment of greenhouse effects are already impacting on global climate systems[2]. Climate change can be observed as a major threat to sustainable growth and development in Africa. Per the outcome, the efforts of African countries to achieve the Sustainable Development Goals (SDGs) may be seen as a mirage if the unfavourable effects of climate change are not investigated. Among the continents which are accountable for climate change, Africa is the least contributor; however, the continent to a greater extend is vulnerable to the effects of climate change due to its over-reliance on rain-fed farming, compounded by components such as widespread poverty and feeble capacity among affected countries. The main long-term impacts of climate change include: worsening water security, changing rainfall patterns to cause reduction in agriculture production and scale-down food security, decreasing fish resources in large lakes due to rising temperature and reposition vector-borne diseases. Furthermore, rising sea level resulting from climate change affects low-lying coastal areas with capacious populations, guiding to increased risk of conflict over water 
resourcefulness and land. The adverse effect from climate change in the form of reduction of agricultural production ends up decelerating the growth of countries in Africa, since a greater proportion of the national income of most African countries is from agriculture. In addition, the agricultural sector aid as the source of livelihood (that is, source of employment) for most people in Africa[3]. Climate change and its impacts are actuality in Ghana. Studies have reported that Ghana's climatic conditions have changed in the past four decades[4] [5]. Over these decades, Ghana documented temperature increase of $1^{\circ} \mathrm{C}$ [4]. In the same time period, runoff and rainfall declined by about $20 \%$ and $30 \%$ respectively[5]. In Ghana, the livelihood backing (agriculture and forestry) and other critical natural resources for rural areas and the country's economy are not free from the grips of climate change in the six ecologic/geographic regions [4]. Yet, most of the studies have centered on environmental aspects of climate change vulnerability and biophysical, while impacts and adaptation works have mostly addressed problems at the national front. Few findings have addressed the social aspects of climate change impacts, vulnerability and adaptation strategies at the local level (households, rural communities, and districts). It is important for more research to center mostly on the social aspects of climate change vulnerability with in-depth examination of the underlying socio-economic statuses that ascertain how the populace reacts to and cope with climate change impacts at the local level. Assessing local level impacts, vulnerability and adaptation is discerning for the development of policy measures that address specific local level needs and avoid one-size-fit-all evaluation that often result from national scale climate change assessment.

Ghana is among countries where climate change is being experienced through the rise in temperatures and unpredictable rainfall across all ecological zones [6]. As far as water resources management and use are concerned, three climate change affiliated issues are relevant: extreme events brought about by changes in sea-level rise and variability, temperature regimes and rainfall [7]. Climate change remains an issue for the whole country, but climate variability is a major challenge, especially for rural areas that depend on natural resources and environmental factors/practices [8]. For rural indigenes without piped water, irregularity and severe in weather patterns (droughts and floods) instantly influence water availability and access, placing additional stresses on their daily activities [7]. According to [8] there is no doubt that the climate in Ghana has changed significantly with impacts being felt in every part of the country. Ghana is among countries where climate change is projected to create water stress by 2025 [7]. In northern Ghana, for instance, high temperatures that were previously recorded in March (peak of the dry season) are now being recorded also in January [9]. The start of the rainy season is becoming increasingly unpredictable. Previously, the rainy season commences in April and ended around late September or early October. Lately, the rainy season starts in June or July with extreme heavy rainfall in September or October, often resulting in floods that destroy life, crops, and properties or ending abruptly and ending in drought conditions [9]. Ghana is experiencing increasing temperatures and irregular rainfall patterns [5] [10]. As these and other modifications become more pronounced in the coming decades, they will likely present challenges to our society and habitat/ environment. There are diverse impacts that climate change is impacting on our environment and livelihood.

For more than a decade, disaster insecurity, water and sanitation insecurity, climate change and energy insecurity have been acknowledged as prominent public health issues [11] [12]. Rise in global temperatures have been accompanied by variations in weather and climate. The planet's oceans and glaciers have also experienced several huge changes. According to [13] Africa is very vulnerable to outcomes of climate change. Accompanying to climate change and variability are rainfall variability, more extreme weather phenomena's and floods are experienced, which severely manifests in Ghana [14].

For decades now climate conditions keep changing making it unpredictable. This has caused continuous decrease in agriculture production, affected water resources and brought upon human's diseases and socio economic instability. Climate change is having a great impact on the agriculture of the Pungu area, which is their main source/origin of income, assessing the adaptation strategies of the impact of climate change in the Pungu community will help the ministry of food and agriculture generate better adaptation strategies for their agriculture and manage well the old adaptations they are using. Therefore, this study seeks to assess climate change adaptation strategies in Pungu community and specifically assesses adaptation strategies to ensure climate change impact on water resources and evaluates strategies employed for sustainable farming/agriculture under climate change in Pungu community, since climate change is having a major impact on agriculture of the Pungu area, which is their main source of income.

\section{Materials and Methods}

\subsection{Study Area and Location}

The study was undertaken at Pungu which lies within the Guinea Savannah woodlands in the Kassena Nankana East Municipal Assembly in the Upper East Region of Ghana, located about $4.5 \mathrm{~km}$ north east of Navrongo, the municipal capital (Figure 1). In Ghana, the Kassena Nankana East Municipality shares edges to the east with Kassena West District and Bolgatanga Municipal, the west with the Builsa District, to the north with Kassena Nankana West District and Burkina Faso and with West Mamprusi District at the south which is located in the Northern Region. 


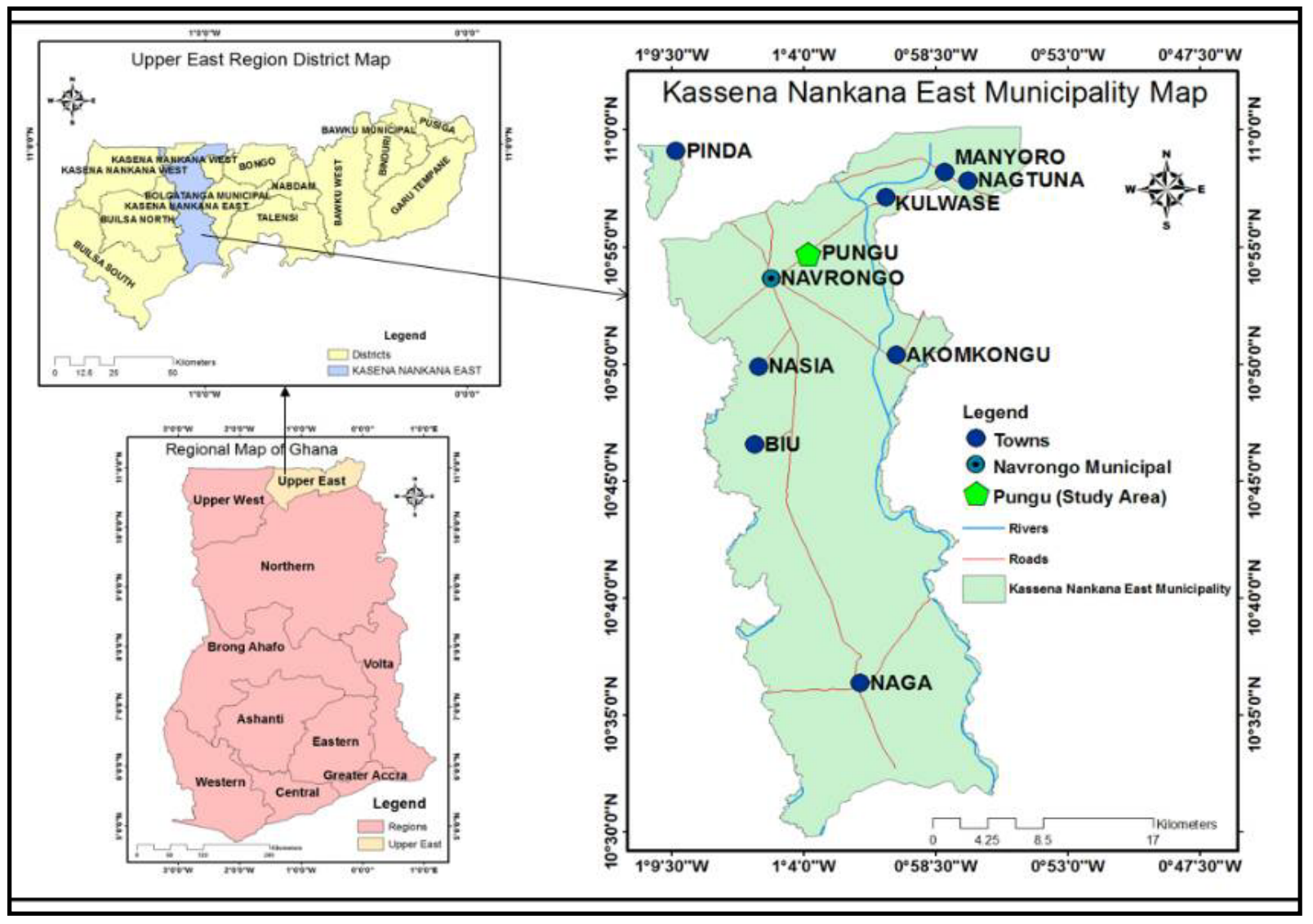

Figure 1. Map of Ghana showing the location of Pungu the study area

\subsection{Soil and Vegetation}

\subsubsection{Vegetation}

The administrative district is covered solely by the Sahel and Sudan-Savannah kinds of vegetation comprising open savannah with fire-swept grassland and deciduous trees. Several of the most densely vegetated parts of the Municipality can be found along river basins and forest reserves. However, exploitation of the original (virgin) vegetation cover by the activities of man has reduced it to open park land and the common trees found are Dawadawa, Baobab, Shea and Mangoes [15].

\subsubsection{Soil}

Savannah ochrosols and groundwater laterite are the predominant soils found in the municipality [16]. The northern and eastern parts of the Municipality are covered by the Savannah ochrosols, while the rest of the municipality is covered by groundwater laterite. The Savannah ochrosols are defined as porous, well drained, loamy, and mildly acidic and interspersed with patches of black or dark-grey clay soils [16]. The groundwater laterites are developed mainly over shale and granite and cover more than half of the municipality's land area. Because of the underlying rock type (granite), they become waterlogged during the rainfall period and dry out during the dry season, thus causing compacted/cemented layers of iron-stone (hard pan), which makes cultivation difficult [15].

\subsection{Climate}

The climatic conditions experienced in the study area are the dry and wet seasons, which are influenced mainly by two (2) air masses - the North-East Trade winds and the South-westerlies (Tropical Maritime).

The harmattan air mass (North-East Trade Winds) is usually dry and dusty as it originates from the Sahara Desert. In the harmattan season rainfall is virtually absent and relative humidity rarely exceeds 20 per cent. The day time temperatures are high recording $42^{\circ} \mathrm{Celsius}$ (especially in February and March) and night time temperatures are as low as $18^{\circ}$ Celsius [16]. The Municipality experiences the tropical maritime air mass between May and October with uni-modal rainfall averaging $950 \mathrm{~mm}$ per annum with reference to [16]. This makes most of the youth in the Municipality idle during the dry seasons (November - April) since farming is the main occupation of the inhabitants and mainly rain fed [15].

\subsection{Climate Change Impacts in Pungu}

Climate changes have caused a lot of impacts nationwide and below are examples of these impacts on the people of 
Pungu community. A change in rainfall pattern is one of the major climate change impact in Kassena Nankana East Municipality, Pungu community to be precise. Initially, the raining season starts from late April or early May to late July, but in recent times the rains start in late May or early June and ends in August. This makes the raining season shorter than it used to be. Changes in farming seasons and planting times are caused by changes in the raining season. Farmers wait on the start of the season to begin with their cultivation; therefore, planting seasons tend to change depending on the start of the rains. Farmers tend to cultivate crops that develop and yield in short period. Hunger/Famine is another impact caused by less food due to poor harvest due to small amount of rain or no rains. Farmers who put their produce on sale will have to keep to feed their families. Temperature increases and decreases drastically causing a lot of harm. Due to climate change, temperature may rise as high as $42^{\circ} \mathrm{C}$ and reduce to as low as $18^{\circ} \mathrm{C}$ in Pungu [16]. During high temperatures, soils and plants lose moisture through evaporation and transpiration respectively. Inhabitants of Pungu sleep outside their rooms due to heat produced by high temperatures and also to help prevent any heat related diseases such as Cerebrospinal Meningitis, heat stress, etc. Other diseases such as malaria may also result due to the extreme climatic changes in the area.

\subsection{Methodology}

Questionnaire administration was the tool used during the study process and simple random sampling techniques was adopted in the selection of units for probe/investigation. Simple random sampling necessitate that each member of the population stands an equal chance of being selected as a subject. The questionnaire was administered to know the various adaptation or coping strategies and to know how effective they are. The scope of the questionnaire includes assessing people's knowledge on climate change, impacts of climate change and assessing the adaptation and coping strategies used to adjust to the impacts made by climate change. The questionnaires were administered to both male and female and across almost all walks of life in the area. The number of questionnaires administered was attained by calculating the sample size of the total population using the formula below by [17]:

$$
n=\frac{N}{1+N(\gamma)^{2}},
$$

where $\mathrm{n}$ is the sample size, $\mathrm{N}$ is the population and $\gamma$ is the margin of error which in this study was chosen as 0.1 with confidence interval of $90 \%$. The population of Pungu community is 7465 [16].

Hence,

$$
n=\frac{7469}{1+(7469 \times 0.1 \times 0.1)}=98.67 \sim 100
$$

Thus 100 respondents were selected for the study meaning one hundred copies of questionnaires were administered as per the total population of Pungu and its surroundings, being 7469 .

\section{Results and Discussion}

\subsection{Gender}

The total number of questionnaires administered was 100 ; with 55 males representing $55 \%$ of the total sample size and 45 females also representing $45 \%$ of the total sample population (Table 1).

Table 1. Gender of respondents

\begin{tabular}{|c|c|c|}
\hline Gender & Frequency & Percentage (\%) \\
\hline Male & 55 & 55.0 \\
\hline Female & 45 & 45.0 \\
\hline Total & $\mathbf{1 0 0}$ & $\mathbf{1 0 0 . 0}$ \\
\hline
\end{tabular}

Source: Authors' Fieldwork (2014)

\subsection{Occupation}

Pungu is predominantly a farming community with a sizeable number of traders and other occupation. Out of the 100 respondents, 37 individuals representing $37 \%$ of the total sample population were farmers; 25 respondents $(25 \%)$ were traders, 21 respondents $(21 \%)$ were students (Figure 2). Literacy level scales down vulnerability by increasing people's capabilities and admittance to information, attainment of skills and better risk acknowledgement thereby enhancing their strength to adapt with climate change adversities [18] and illiteracy serves as a barrier in facilitating understanding of the complex nature of hazards and appropriate responses to them [19], this implies that, $21 \%$ of the respondent stand a chance of coping with climate change adversities due to their level of literacy rate. About 17 respondents (17\%) were into other occupations such as teaching, health, etc.

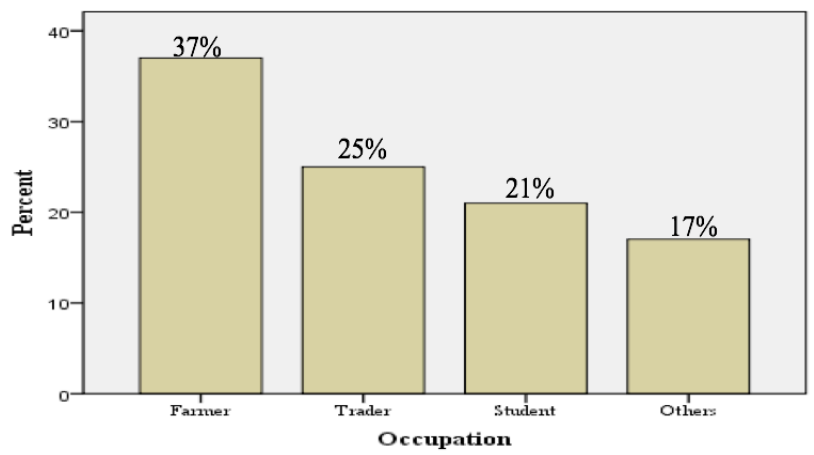

Source: Authors' Fieldwork (2014)

Figure 2. Occupation of respondents 


\subsection{Adaptation Strategies}

Adaptation strategies used in Pungu to cope with climate change are as follows;

\subsubsection{Adaptation Strategies to Manage Water Resources}

These are ways and means by which water resources are used in order to cope with impacts that climate change has on the water resources. Examples of such strategies are the use of shallow wells or hand-dug wells alongside boreholes as water resources and rainfall harvesting. These practices are used for agricultural purposes and domestic chores like cooking, washing, etc. There was no sign of a running stream in the town as at the time of the study (i.e. during the dry season).

Table 2 and Table 3 below show the distribution of respondents' views on these strategies;

Table 2. Response per shallow wells and hand-dug wells

\begin{tabular}{|c|c|c|c|c|c|c|c|}
\hline & & \multicolumn{5}{|c|}{$\begin{array}{c}\text { The use of shallow wells and hand-dug wells as an } \\
\text { adaptation strategy }\end{array}$} & \multirow[b]{2}{*}{ Total } \\
\hline & & Excellent & Very good & Good & Fairly good & Poor & \\
\hline \multirow{4}{*}{ Occupation } & Farmer & 5 & 4 & 19 & 5 & 4 & 37 \\
\hline & Trader & 3 & 8 & 11 & 2 & 1 & 25 \\
\hline & Student & 1 & 7 & 10 & 3 & 0 & 21 \\
\hline & Others & 3 & 3 & 4 & 6 & 1 & 17 \\
\hline Total & & 12 & 22 & 44 & 16 & 6 & 100 \\
\hline
\end{tabular}

Source: Authors' Fieldwork (2014)

From Table 2, 12 individuals representing 12\% of the total sample population said the use of shallow wells and hand-dug wells is an excellent adaptation strategy. About 22 respondents (22\%) also said is a very good strategy, 44 people (44\%) also said it was Good. About 16 people (16\%) however said it was fairly good and 6 individuals (6\%) also said it was a poor adaption strategy. Table 3 shows that, 17 respondents representing $17 \%$ of the total sample population said it is an excellent adaptation strategy to harvest rain for use in the dry season. Another 17 respondents (17\%) also said is a very good strategy, 26 people $(26 \%)$ said it was Good. Some of the people $(23 \%)$ however, said it was fairly good whiles 17 individuals (17\%) also said it was a poor adaption strategy. This shows that, this particular strategy is not appreciated by the masses in the community.

Table 3. Response per harvesting of rain

\begin{tabular}{|ll|c|c|c|c|c|c|}
\hline & \multicolumn{6}{|c|}{ Harvesting rain for use in dry season as an adaptation } & \\
\cline { 3 - 7 } & & Excellent & Very good & Good & Fairly good & Poor & Total \\
\hline Occupation & Farmer & 6 & 5 & 15 & 6 & 5 & $\mathbf{3 7}$ \\
& Trader & 3 & 10 & 4 & 0 & 8 & $\mathbf{2 5}$ \\
& Student & 3 & 2 & 4 & 10 & 2 & $\mathbf{2 1}$ \\
& Others & 5 & 0 & 3 & 7 & 2 & $\mathbf{1 7}$ \\
Total & & $\mathbf{1 7}$ & $\mathbf{1 7}$ & $\mathbf{2 6}$ & $\mathbf{2 3}$ & $\mathbf{1 7}$ & $\mathbf{1 0 0}$ \\
\hline
\end{tabular}

Source: Authors' Fieldwork (2014)

\subsection{Adaptation Strategies for Food Security}

These strategies are meant to ensure a constant and abundant food supply for the community and beyond. Examples of these strategies are; growing of vegetables and post-harvest storage. Table 4 and 5 indicate views of the respondents concerning these two examples; 
Table 4. Response per growing of vegetables

\begin{tabular}{|c|c|c|c|c|c|c|c|}
\hline & \multicolumn{4}{|c|}{ Growing vegetables as an adaptation strategy } & \multirow{2}{*}{ Total } \\
\cline { 3 - 7 } & & Excellent & Very good & Good & Fairly good & Poor & (19 \\
\hline Occupation & Farmer & 8 & 19 & 2 & 5 & 3 & $\mathbf{3 7}$ \\
& Trader & 5 & 3 & 11 & 6 & 0 & $\mathbf{2 5}$ \\
& Student & 2 & 6 & 6 & 5 & 2 & $\mathbf{2 1}$ \\
& Others & 4 & 4 & 6 & 1 & 2 & $\mathbf{1 7}$ \\
Total & & $\mathbf{1 9}$ & $\mathbf{3 2}$ & $\mathbf{2 5}$ & $\mathbf{1 7}$ & $\mathbf{7}$ & $\mathbf{1 0 0}$ \\
\hline
\end{tabular}

Source: Authors' Fieldwork (2014)

From Table 4, 19 individuals representing 19\% of the total sample population said it is an excellent strategy to grow vegetables for food security. About 32 respondents (32\%) also said it is a very good strategy, 25 people (25\%) also said it was Good. About 17 people (17\%) however said it was fairly good and 7 individuals (7\%) also said it was a poor adaption strategy.

Since a greater percentage of the individuals from the total sample population responded positively to the growing of vegetables as an adaptation strategy, then it suggests that the strategy is acceptable to them.

Table 5. Response per post-harvest storage

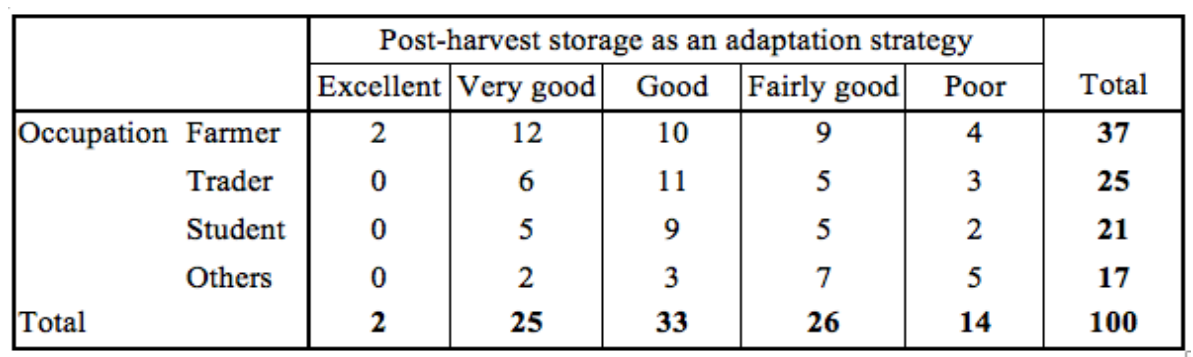

Source: Authors' Fieldwork (2014)

From Table 5, 2 individuals representing $2 \%$ of the total sample population said it is a remarkable strategy to keep food after gathering as to ensure food security and safety. About 25 respondents (25\%) also said it is a very good strategy, 33 people (33\%) also said it was Good. Some of the people (26\%) however said it was fairly good with 14 individuals (14\%) also saying it was a poor adaption strategy. Even though a greater percentage of the individuals from the total sample population responded positively to post-harvest storage as an adaptation strategy, a sizable number of the population also thinks it is poor.

\subsection{Adaptation Strategies for Health}

These are strategies used to ensure disease prevention and control. Examples of these strategies are; sleeping outdoors to prevent heat related diseases such as Cerebrospinal Meningitis (CSM), heat stress among others and also sleeping under treated mosquito nets. Tables 6 and 7 show the views of the respondents concerning these two examples;

Table 6. Response per sleeping outdoors

\begin{tabular}{|c|c|c|c|c|c|c|c|}
\hline & & \multicolumn{5}{|c|}{$\begin{array}{l}\text { Sleeping outdoors to prevent heat related diseases is an } \\
\text { adaptation strategy }\end{array}$} & \multirow[b]{2}{*}{ Total } \\
\hline & & Excellent & Very good & Good & Fairly good & Poor & \\
\hline \multirow[t]{4}{*}{ Occupation } & Farmer & 11 & 8 & 9 & 9 & 0 & 37 \\
\hline & Trader & 2 & 3 & 12 & 4 & 4 & 25 \\
\hline & Student & 10 & 6 & 2 & 3 & 0 & 21 \\
\hline & Others & 3 & 3 & 2 & 5 & 4 & 17 \\
\hline Total & & 26 & 20 & 25 & 21 & 8 & 100 \\
\hline
\end{tabular}

Source: Authors' Fieldwork (2014)

From Table 6,26 people representing $26 \%$ of the total sample population said it is an excellent strategy to sleep outside during heat seasons in order to prevent heat related diseases. About 20 respondents (20\%) also said it is a very good strategy, 25 people (25\%) also said it was Good. About 21 people (21\%) however said it was fairly good and 8 individuals 
$(8 \%)$ also said it was a poor adaption strategy.

Table 7. Response per the use of mosquito-treated nets

\begin{tabular}{|c|c|c|c|c|c|c|c|}
\hline & \multicolumn{4}{|c|}{ Usage of mosquito nets is an adaptation strategy } & \multirow{2}{*}{} \\
\cline { 3 - 7 } & & Excellent & Very good & Good & Fairly good & Poor & Total \\
\hline Occupation & Farmer & 13 & 16 & 4 & 4 & 0 & $\mathbf{3 7}$ \\
& Trader & 8 & 8 & 5 & 2 & 2 & $\mathbf{2 5}$ \\
& Student & 5 & 11 & 4 & 0 & 1 & $\mathbf{2 1}$ \\
& Others & 5 & 5 & 2 & 3 & 2 & $\mathbf{1 7}$ \\
Total & & $\mathbf{3 1}$ & $\mathbf{4 0}$ & $\mathbf{1 5}$ & $\mathbf{9}$ & $\mathbf{5}$ & $\mathbf{1 0 0}$ \\
\hline
\end{tabular}

Source: Authors' Fieldwork (2014)

Table 7 shows that, 31 respondents representing $31 \%$ of the total sample population said it is a splendid strategy to sleep under treated-mosquito nets in order to prevent disease. About 40 respondents $(40 \%)$ also said it is a very good strategy, 15 people (15\%) also said it was Good. About 9 people (9\%) however, said it was fairly good whiles 5 individuals $(5 \%)$ also said it was a poor adaption strategy. Since a greater percentage of the individuals from the total sample population responded positively to sleeping outside to prevent heat related diseases and also the use of mosquito-treated nets as adaptation strategy for health, then it suggests that these strategies are acceptable to the people of Pungu.

\subsection{Adaptation Strategies for Agriculture}

These are strategies used to ensure adequate utilization and efficient maintenance of the agricultural resources (lands, crops, etc.). Examples of this strategy are shifts in planting season to coincide with the start of rainy season, planting on raised ridges, farming during minor raining season, mixed farming, sales of livestock, improving soil nutrients, planting drought resistant crops varieties and the use of modern seeds.

Climate change introduces numerous uncertainties to the livelihoods of farming areas that rely heavily on the weather and climate [20] as reported by [21], the fundamental/basic elements of crop production such as soil, water and biodiversity are negatively affected by climate change.

Tables 8 to 15 show the views of respondents concerning the aforementioned strategies;

Table 8. Response per shifts in planting season

\begin{tabular}{|c|c|c|c|c|c|c|}
\hline & & \multicolumn{4}{|c|}{$\begin{array}{l}\text { Shifts in planting season to coincide with the start of the } \\
\text { raining season is an adaptation strategy }\end{array}$} & \multirow[b]{2}{*}{ Tota } \\
\hline & & Excellent & Very good & Good & Fairly good & \\
\hline \multirow[t]{4}{*}{ Occupation } & Farmer & 5 & 27 & 3 & 2 & 37 \\
\hline & Trader & 9 & 11 & 5 & 0 & 25 \\
\hline & Student & 8 & 9 & 3 & 1 & 21 \\
\hline & Others & 5 & 8 & 4 & 0 & 17 \\
\hline Total & & 27 & 55 & 15 & 3 & 100 \\
\hline
\end{tabular}

Source: Authors' Fieldwork (2014)

From Table 8, 27 people representing $27 \%$ of the total sample population said it is an excellent strategy to shift planting seasons to coincide with the time of rain in the year. About 55 respondents (55\%) also said it is a very good strategy, 15 people (25\%) also said it was Good and 3 people (3\%) however said it was fairly good. None of the respondents voted for poor on this adaption strategy.

Table 9. Response per planting on raised ridges

\begin{tabular}{|c|c|c|c|c|c|c|c|}
\hline & \multicolumn{5}{|c|}{ Planting on raised ridges is an adaptation strategy } & \multirow[b]{2}{*}{ Total } \\
\hline & & Excellent & Very good & Good & Fairly good & Poor & \\
\hline \multirow[t]{4}{*}{ Occupation } & Farmer & 4 & 11 & 13 & 9 & 0 & 37 \\
\hline & Trader & 6 & 4 & 7 & 8 & 0 & 25 \\
\hline & Student & 2 & 10 & 9 & 0 & 0 & 21 \\
\hline & Others & 0 & 3 & 9 & 3 & 2 & 17 \\
\hline Total & & 12 & 28 & 38 & 20 & 2 & 100 \\
\hline
\end{tabular}

Source: Authors' Fieldwork (2014) 
Table 9 shows that, 12 people representing $12 \%$ of the total sample population said it is an excellent strategy to plant on raised ridges. About 28 respondents (28\%) also said it is a very good strategy, 38 people (38\%) also said it was Good and 20 people (20\%) however said it was fairly good and 2 respondents $(2 \%)$ voted for poor on this adaption strategy.

Low soil organic matter below $2 \%$ in the topsoil and high iron concretion levels with severe erosion susceptibility [22] is the nature of savannah zones soils hence, periodical incorporation of manure into the savannah zones soils is demanded [23] since limited availability of plant nutrients (in the form of phosphorus and nitrogen) is constraints to agricultural productivity in Pungu. These constraints are further impeded in the northern savanna zones by substantial topsoil losses through water and wind erosion [24], thus the need for planting on raised ridges in the Pungu community to support plant growth during the rainy season. However, during the dry season the farmers' should plant in the channels between the ridges to conserve irrigated water.

Table 10. Response per farming during minor raining season (late farming)

\begin{tabular}{|c|c|c|c|c|c|c|c|}
\hline & & \multicolumn{5}{|c|}{$\begin{array}{l}\text { Farming during minor raining season is an adaptation } \\
\text { strategy }\end{array}$} & \multirow[b]{2}{*}{ Total } \\
\hline & & Excellent & Very good & Good & Fairly good & Poor & \\
\hline \multirow[t]{4}{*}{ Occupation } & Farmer & 5 & 2 & 3 & 21 & 6 & 37 \\
\hline & Trader & 1 & 7 & 4 & 7 & 6 & 25 \\
\hline & Student & 2 & 5 & 8 & 2 & 4 & 21 \\
\hline & Others & 0 & 4 & 4 & 4 & 5 & 17 \\
\hline Total & & 8 & 18 & 19 & 34 & 21 & 100 \\
\hline
\end{tabular}

Source: Authors' Fieldwork (2014)

Northern Ghana, unlike the South does not necessarily have major and minor rainfall periods but rather a single raining season. In this study the minor season means from October to November when the rainfall season is coming to an end after peaking in August and September. Table 10 shows that, 8 people representing $8 \%$ of the total sample population said it is an excellent strategy to farm during minor raining season (late farming). About 18 respondents (18\%) also said it is a very good strategy, 19 people (19\%) also said it was Good and 34 people (34\%) however said it was fairly good and 21 respondents (21\%) voted for poor on this adaption strategy.

The Forest-Savanna Transition, Guinea Savanna and Coastal Savanna ecological zones are jutted out to be of the highest degree affected through shortened farming seasons and droughts [25]. This signifies that, the minor raining season is very inadequate for their farming activities and would therefore not be advisable to cultivate during this time.

Table 11. Response per mixed farming

\begin{tabular}{|ll|c|c|c|c|c|}
\hline & & \multicolumn{3}{|c|}{ Mixed farming is an adaptation strategy } & \multirow{2}{*}{ Total } \\
\cline { 3 - 6 } & & Excellent & Very good & Good & Fairly good & To \\
\hline Occupation & Farmer & 14 & 20 & 3 & 0 & $\mathbf{3 7}$ \\
& Trader & 6 & 9 & 5 & 5 & $\mathbf{2 5}$ \\
& Student & 8 & 9 & 4 & 0 & $\mathbf{2 1}$ \\
& Others & 3 & 7 & 6 & 1 & $\mathbf{1 7}$ \\
Total & & $\mathbf{3 1}$ & $\mathbf{4 5}$ & $\mathbf{1 8}$ & $\mathbf{6}$ & $\mathbf{1 0 0}$ \\
\hline
\end{tabular}

Source: Authors' Fieldwork (2014)

According to Table 11 above, 31 respondents representing $31 \%$ of the total sample population said it is an excellent strategy to carry out mixed farming. About 45 respondents (45\%) also said it is a very good strategy, 18 people (18\%) also said it was Good. About 6 people (9\%) however said it was fairly good whiles none of the respondents voted for poor on this adaption strategy.

This signifies that it is a highly acceptable strategy and needs to be encouraged among the residents of Pungu since most smallholder farmers in Pungu combine different approaches to meet food security and their cash flow needs. 
Table 12. Response per sale of livestock

\begin{tabular}{|c|c|c|c|c|c|c|c|}
\hline & \multicolumn{5}{|c|}{ Sales of livestock is an adaptation strategy } & \multirow[b]{2}{*}{ Total } \\
\hline & & Excellent & Very good & Good & Fairly good & Poor & \\
\hline \multirow[t]{4}{*}{ Occupation } & Farmer & 3 & 19 & 7 & 6 & 2 & 37 \\
\hline & Trader & 2 & 5 & 4 & 7 & 7 & 25 \\
\hline & Student & 2 & 14 & 3 & 0 & 2 & 21 \\
\hline & Others & 2 & 2 & 4 & 1 & 8 & 17 \\
\hline Total & & 9 & 40 & 18 & 14 & 19 & 100 \\
\hline
\end{tabular}

Source: Authors' Fieldwork (2014)

Table 12 shows that, 9 people representing $9 \%$ of the total sample population said it is an excellent strategy to sell livestock in order to get income to improve farming practices, livelihood and implements. 40 respondents $(40 \%)$ also said it is a very good strategy, 18 people (18\%) also said it was Good and 14 people (14\%) however said it was fairly good and 19 respondents $(19 \%)$ voted for poor on this adaption strategy.

This signifies that, the response is defused and therefore the strategy is not out rightly acceptable. However, $9 \%$ excellent and $40 \%$ very good indicates that livestock rearing should be encouraged as an adaptation strategy in the area since livestock production will help to generate income for livelihood support to the people of Pungu community.

Table 13. Response per soil nutrient improvement

\begin{tabular}{|cl|c|c|c|c|c|}
\hline & \multicolumn{2}{|c|}{ Improving soil nutrients is an adaptation strategy } & \multirow{2}{*}{} \\
\cline { 3 - 6 } & & Excellent & Very good & Good & Fairly good & Total \\
\hline Occupation & Farmer & 10 & 22 & 5 & 0 & $\mathbf{3 7}$ \\
& Trader & 6 & 5 & 10 & 4 & $\mathbf{2 5}$ \\
& Student & 10 & 4 & 7 & 0 & $\mathbf{2 1}$ \\
& Others & 5 & 7 & 5 & 0 & $\mathbf{1 7}$ \\
Total & & $\mathbf{3 1}$ & $\mathbf{3 8}$ & $\mathbf{2 7}$ & $\mathbf{4}$ & $\mathbf{1 0 0}$ \\
\hline
\end{tabular}

Source: Authors' Fieldwork (2014)

From Table 13,31 people representing $31 \%$ of the total sample population said it is an excellent strategy to improve soil nutrients. About 38 respondents (38\%) also said it is a very good strategy, 27 people (27\%) also said it was Good and 4 people (4\%) however said it was fairly good. None of the respondents voted for poor on this adaption strategy. According to this response, the use of manure (poultry droppings, cow dung, etc.) and fertilizers to improve the soil nutrients to augment fertility of the land is highly acceptable.

Table 14. Response per planting drought resistant crop varieties and fruits

\begin{tabular}{|c|c|c|c|c|c|c|c|}
\hline & \multicolumn{5}{|c|}{ Planting drought resistant crop varieties and fruits } & \multirow[b]{2}{*}{ Total } \\
\hline & & Excellent & Very good & Good & Fairly good & Poor & \\
\hline \multirow[t]{4}{*}{ Occupation } & Farmer & 5 & 6 & 19 & 5 & 2 & 37 \\
\hline & Trader & 7 & 9 & 6 & 2 & 1 & 25 \\
\hline & Student & 1 & 10 & 3 & 5 & 2 & 21 \\
\hline & Others & 3 & 5 & 2 & 5 & 2 & 17 \\
\hline Total & & 16 & 30 & 30 & 17 & 7 & 100 \\
\hline
\end{tabular}

Source: Authors' Fieldwork (2014)

Table 14 shows that, 16 people representing $16 \%$ of the total sample population said it is an excellent strategy to plant drought resistant crop varieties and fruits. About 30 respondents (30\%) also said it is a very good strategy, 30 people (30\%) also said it was Good and 17 people (17\%) however said it was fairly good and 7 respondents (7\%) voted for poor on this adaption strategy. The response indicates that introduction of drought resistant crops will be welcomed by the residents of the area. 
Table 15. Response per the use of modern seeds

\begin{tabular}{|c|c|c|c|c|c|c|c|}
\hline & & \multicolumn{5}{|c|}{ Use of modern seeds is an adaptation strategy } & \multirow[b]{2}{*}{ Total } \\
\hline & & Excellent & Very good & Good & Fairly good & Poor & \\
\hline \multirow[t]{4}{*}{ Occupation } & Farmer & 6 & 1 & 10 & 13 & 7 & 37 \\
\hline & Trader & 3 & 3 & 5 & 8 & 6 & 25 \\
\hline & Student & 3 & 4 & 5 & 7 & 2 & 21 \\
\hline & Others & 2 & 4 & 2 & 6 & 3 & 17 \\
\hline Total & & 14 & 12 & 22 & 34 & 18 & 100 \\
\hline
\end{tabular}

Source: Authors' Fieldwork (2014)

Table 15 shows that, 14 people representing $14 \%$ of the total sample population said it is an excellent strategy to use modern seed. About 12 respondents (12\%) also said it is a very good strategy, 22 people (22\%) also said it was Good and 34 people (34\%) however said it was fairly good and 18 respondents $(18 \%)$ voted for poor on this adaption strategy.

This signifies that, the response is defused and therefore the strategy is not out rightly acceptable. This is due to the fact that most of the indigenes who indulge in subsistence farming do not get a supply of these types of seeds. Others who may acquire them also mostly do not apply the most required precautions concerning the use of these seeds.

\subsubsection{Adaptation Strategies for Socio-Economic Stability}

These are strategies employed during non-planting season in order to ensure sustained livelihood. Examples of this strategy are migration to other parts of the country and economic diversity (e.g. pito brewing ). Table 16 shows the views of respondents concerning the aforementioned strategies;

Table 16. Response per migration to other parts of the country

\begin{tabular}{|c|c|c|c|c|c|c|c|}
\hline & & \multicolumn{5}{|c|}{$\begin{array}{l}\text { Migration to other parts of the country is an adaptation } \\
\text { strategy }\end{array}$} & \multirow[b]{2}{*}{ Total } \\
\hline & & Excellent & Very good & Good & Fairly good & Poor & \\
\hline \multirow{4}{*}{ Occupation } & Farmer & 2 & 2 & 0 & 14 & 19 & 37 \\
\hline & Trader & 1 & 5 & 3 & 6 & 10 & 25 \\
\hline & Student & 2 & 0 & 4 & 4 & 11 & 21 \\
\hline & Others & 1 & 0 & 1 & 1 & 14 & 17 \\
\hline Total & & 6 & 7 & 8 & 25 & 54 & 100 \\
\hline
\end{tabular}

Source: Authors' Fieldwork (2014)

Owing to Table 16, 6 people representing $6 \%$ of the total sample population said it is an excellent strategy to migrate to other parts of the country to quest greener pastures in times of the non-farming seasons. About 7 respondents (7\%) also said it is a very good strategy, 8 people ( $8 \%$ ) also said it was Good and 25 people $(25 \%)$ however said it was fairly good and 54 respondents $(54 \%)$ voted for poor on this adaptation strategy. This demonstrates that, it is highly unacceptable to migrate to other parts of the country to seek greener pastures during non-planting season. They would rather stay in the community and wait for the rains to set in.

Table 17. Responses per economic diversification (basketry, pito brewing, etc.)

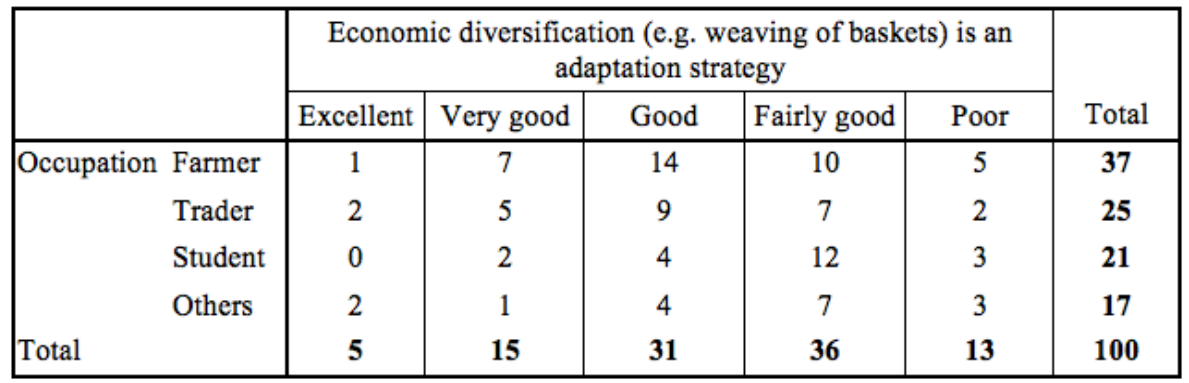

Source: Authors' Fieldwork (2014) 
Table 17 shows that 5 people representing $5 \%$ of the total sample population said it is an excellent strategy to embark on economic diversification. About 15 respondents $(15 \%)$ also said it is a very good strategy, 31 people $(31 \%)$ also said it was Good and 36 people $(36 \%)$ however said it was fairly good and 13 respondents (13\%) voted for poor on this adaption strategy.

This also shows a defused response and therefore the strategy is not out rightly acceptable to the respondents.

The general findings of the study brought to light a better understanding about the adaptation strategies relationship of health, water resource managements, agriculture, food security and socio-economic stability on climate change effect in Pungu. Based on the review, we can infer that, farming as an occupation tend to have more economically active dependents on rainfall which in turn increases vulnerability in terms of occupation since farming is the predominate occupation in the area and rainfall is the primary source for indulging in farming activities in Pungu. In relation to occupation, since the Pungu is predominantly a farming area, a lot of the trader's trade in farm produce and as a result a high linkage is expected since these two (farming and trade) occupations largely depend on water and the environment if they are to see any gains. Additionally, the high link may be due to the fact that most of the traders are either related to the farmers or work directly with them. On the other hand, a smaller relation was observed between Farmers and Others (students and others) occupation. This was possibly due to the fact that these other occupations were not directly related to farming. Relating to health, change in temperature decides the sleeping adaptation strategy to be used by inhabitants since the breed of mosquito and heat related disease are predominant in the rainy season and high temperature periods respectively. People who are literate (students) depend more on information to attain skills that have influenced on climate-sensitive occupations like farming since they are able to diversify occupations or source of income to generate some manner of livelihood insurance against life uncertainties in order to reduce access to climate change vulnerabilities or impacts with high level of risk acknowledgement to their livelihoods. The use of shallow wells or hand-dug wells alongside boreholes as water resources and rainfall harvesting are the main domestic and agriculture water management adaptation strategies used in Pungu. Access to storage and the utilization of post harvest practices known by the Pungu people, post-harvest storage was the excellent adaptation strategy effectively utilized for food security. Diversified income sources such as trading, or migrating to southern part of the country to work provide some form of income and welfare insurance against shocks and reduces vulnerability to delay in planting in the farming season as a results of rainfall delay and off-farming seasons. In Pungu, occupations that depend primarily on the climate for production tend to be farming which was realized to be vulnerable to climate change, hence changing climatic conditions disrupts production which in turn affect livelihood. Information on mixed farming dissemination by correspondence revealed the access to income generation from the sales of livestock and the use of the farm yard manure in enriching the soil as agriculture adaptation strategy. Economic diversification information of Pungu was known to promote resilience in the face of climate change events but limited access to relevant climate change information increases vulnerability to Pungu people because, heavy dependency on agriculture activities solely indicates narrow range of livelihood options but off-farm season activities provides security for socio-economic stability.

\section{Conclusions}

Adaptation strategies identified in Pungu were grouped into five categories, namely; health, water resource managements, agriculture, food security and socio-economic stability.

Two adaptation strategies were identified under health in Pungu and these strategies pertain to the extremities in temperatures. When temperatures are high, residents sleep outdoors to prevent heat related diseases such as Cerebrospinal meningitis and heat stress. Also during the raining season, residents sleep in treated mosquito nets due to the increase in the breed of mosquitoes.

The inhabitants of Pungu community are mostly farmers by occupation, and their main source of water for farming is the rains. Alterations in rainfall forms have caused them to shift their planting times to coincide with beginning of the rains. Some of the farmers have as well resorted to mixed farming and planting of drought resistant crop varieties. They also improve the fertility of the soil by the application of manure or fertilizers for high yield. The sale of livestock has also aided in the enhanced livelihood of the people of Pungu community.

Post-harvest culture which ensures efficient storage of food for posterity and cultivation of vegetables for use and sale in the markets is also practiced by the indigenes of Pungu.

During off-farming season or when farming activities are not providing enough to sustain the residents of Pungu, some resort to different occupations such as brewing of pito, rendering security services to local businesses among others. Others however migrate to other parts of the country to seek greener pastures.

It is recommended that more seminars and workshops should be held by municipal assembly on the awareness of climate change, its impacts and adaptation strategies in Pungu. The Ministry of Food and Agriculture (MoFA) should intensify their extension service and make provisions for all farmers; both commercial and subsistence and also innovate the farmers to more modern 
adaptation strategies such as the use of improved seeds.

\section{REFERENCES}

[1] Zoellick. S, Robert B.A. Climate Smart Future. The Nation Newspapers. Vintage Press Limited, Lagos, Nigeria, pp 18. 2009.

[2] Hulme. M, Doherty. R, Ngara. T, New. M and Lister D. African climate change: 1900-2100, Clim. Res., 17 , 145$168,2001$.

[3] Asante. F, Amuakwa-Mensah. F. Climate Change and Variability in Ghana: Stocktaking, Climate, 3 , 78-99, 2014.

[4] Dumenu. W. K, Obeng, E. A. Climate change and rural communities in Ghana: Social vulnerability, impacts, adaptations and policy implications, Environ. Sci. Policy, $55,208-217.2016$.

[5] EPA. Ghana's Initial National Communication under the United National Framework Convention on Climate Change. Environmental Protection Agency, Accra, 2000.

[6] Ministry of Environment, Science and Technology. Message from the vice president and foreword by the minister of environment, science and technology. In Ghana Goes for Green Growth; Ministry of Environment, Science and Technology: Accra, Ghana, 2010.

[7] John. F. G, Kenneth. O. M. Climate Change as a Wicked Problem: An Evaluation of the Institutional Context for Rural Water Management in Ghana 2012. Online available from http://journals.sagepub.com/doi/abs/10.1177/21582440124 48487.

[8] Van der Geest, K. "We're managing" climate change and livelihood vulnerability in Northwest Ghana. Leiden, Netherlands: African Studies Centre, 2004.

[9] Kankam-Yeboah. K, Amisigo. B, and Obuobi. E. 2011. Climate change Impact on Water Resources in Ghana, Ghana National Commission for UNESCO, 2011. Online available from

www.natcomreport.com/ghana/livre/climate-change.pdf

[10] Nelson. W, Agbey, S.N.D. Linkage between Poverty and Climate Change: Adaptation of the Livelihood for the Poor in Ghana. National Development Planning Commission and Friends of the Earth Ghana, Accra. Technical paper, pp. 71. 2005.

[11] Oldfield. E. Addressing Energy Poverty Through Smarter Technology. Bulletin of Science, Technology and Society, 31(2), 113, 2011. Retrieved from SAGE Publications.

[12] Teelucksingh. C, Poland. B. Energy Solutions, Neo-Liberalism, and Social Diversity in Toronto, Canada.
International Journal of Environmental Research and Public Health, 8(1), 185, 2011. Retrieved from Molecular Diversity Preservation International (MDPI).

[13] IPCC. In: Core Writing Team, Pachauri, R.K., Reisinger, A. (Eds.), Contribution of Working Groups I, II and III to the Fourth Assessment Report of the Intergovernmental Panel on Climate Change. IPCC, Geneva, 2007.

[14] EPA, MEST, Ghana's Second National Communication to the UNFCCC. Environmental Protection Agency and Ministry of Environment, Science and Technology, Accra. 2011.

[15] Ministry of Food and Agriculture Ghana (MOFA) 2014. Online Available from http://mofa.gov.gh/site/?page_id=1654

[16] Census Report. Population and Housing Census, District Analytical Report, Kasena Nankana East Municipality, 2010.

[17] Puopiel. F. Solid waste management in Ghana: The case study of Tamale metropolitan area Unpublished MSc Thesis, Kwame Nkrumah University of Science and Technology, Ghana, p.22, 2010.

[18] Wongbusarakum. S, Loper, C. Indicators to Assess Community Level Social Vulnerability to Climate Change: An Addendum to SocMon and SEM Pasifika Regional Socioeconomic Monitoring Guidelines. 2011.

[19] Brooks. N, Adger. W.N and Kelly. P.M. The determinants of vulnerability and adaptive capacity at the national level and the implications for adaptation. Global Environ. Chang. 15, 151-163. 2005.

[20] Athula. S, Scarborough, H. Coping with climatic variability by rain-fed farmers in dry zone. In Proceedings of the 55th Conference of Sri Lanka: Towards Understanding Adaptation to Climate Change, Melbourne, Australia, 8-11 February 2011.

[21] Food and Agriculture Organization. The State of Food Insecurity in the World 2008; Food and Agriculture Organization: Rome, Italy, 2009.

[22] Kwame Oppong-Anane. Country Pasture/Forage Resource Profiles. Food and Agriculture Organization of the United Nations (FAO) 2006. Online Available from http://www.fao.org/ag/AGP/AGPC/doc/Counprof/ghana/G hana.htm.

[23] (MoFA) Ministry of Food and Agriculture. National soil fertility management action plan. Directorate of Crop Services. Accra. Ghana. 1998.

[24] Felix. A. A, Amuakwa-Mensah .F. Climate Change and Variability in Ghana: Stocktaking Climate, 3, 78-99; 2015. doi:10.3390/cli3010078 climate ISSN 2225-1154 www.mdpi.com/journal/climate.

[25] Yaro. J. The Social Dimensions of Adaptation to Climate Change in Ghana. The World Bank, Washington, DC 2010. 